Mineralogical Journal, Vol. 3, Nos. 5 \& 6, pp. 338-344, Aug., 1962

\title{
DJURLEITE, A NEW COPPER SULPHIDE MINERAL
}

\author{
NOBUO MORIMOTO \\ Mineralogical Department, University of Tokyo
}

\begin{abstract}
Djurleite, a new copper sulphide of or about $\mathrm{Cu}_{1.96} \mathrm{~S}$ composition, is described. Chalcocite-like materials from several localities in Japan and in U.S. A. are identified as the new phase first synthesized by Djurle. The density is 5.63. The X-ray powder data are in complete agreement with those given by Djurle. The symmetry is orthorhombic. The composition is not accurately determined but appears to be approximately $\mathrm{Cu}_{1.96} \mathrm{~S}$. Djurleite is found as a primary and secondary mineral associated with one or more of the following mincrals: digenite, bornite, chalcopyrite and pyrite.
\end{abstract}

\section{Introduction}

In the course of recent $\mathrm{X}$-ray studies of the ternary $\mathrm{Cu}_{2} \mathrm{~S}-\mathrm{Cu}_{9} \mathrm{~S}_{5}$ $\mathrm{Cu}_{5} \mathrm{FeS}_{4}$ solid solution series, a number of natural sulphides were investigated by the present writer and his collaborators (Morimoto and Kullerud, 1961 ${ }^{6)}$; Morimoto and Kullerud, in press). Of these specimens, chalcocite-like single crystals from the Ani mine, Akita Prefecture, Japan, gave complex diffraction patterns which showed orthorhombic symmetry in the precession photographs, and which were quite different from those of chalcocite and digenite as well as of bornite. They were, however, in complete agreement with those obtained from certain compounds with compositions between digenite and chalcocite, synthesized by Kullerud in 1958. When the patterns were first obtained from the synthetic single crystals in the study of Morimoto and Kullerud ${ }^{5}$, they were thougt to belong to a metastable phase with composition between digenite and chalcocite, but were not studied in detail at that time. The agreement between the material from the Ani mine and this synthetic material indicates 
that this phase also occurs in nature. Greig (private communication) suggested that the Ani mine material might be the new phase of composition $\mathrm{Cu}_{1.96} \mathrm{~S}$ (Djurle, 1958)2).

So far materials from five localities, including the Ani mine, have been identified as $\mathrm{Cu}_{1.96} \mathrm{~S}$. These localities are the Osarizawa mine, Akita, the Rendaiji mine, Shizuoka, and the Nakauri mine, Shizuoka, all in Japan, and the Leonard mine, Butte, Montana, U.S. A. The writer proposes to give the name djurleite to this new mineral after S. Djurle who first synthesized the compound*.

\section{Occurrence and mineral association}

The specimens from the Ani mine, collected by Aoki and supplied by Sakurai, are single crystals of euhedral forms growing on quartz. The crystals appear to have grown directly by deposition from a solution as a primary mineral.

Jimbo $^{3)}$ studied the material from the Osarizawa mine and identified it as harrisite", which he believed on the basis of morphology, cleavege and blow pipe experiments, to be a pseudomorph of chalcocite after galena. The mineral occurs in aggregates of cube crystals with small octahedral faces showing galena-like cleavages. Some of the large crystals are $2 \mathrm{~cm}$. long. The "single" crystals, however, consist of fine crystallites, apparently pseudomorphs after galena. The colour is dark lead-grey and bluish black. The density determined pycnometrically is 5.63 .

The specimen from the Leonard mine (U. S. National Museum No. R-9925) was supplied by Switzer in 1959, and is labelled as chalcocite. It consists of aggregates of fine crystallites and is associated with digenite, bornite and very small amounts of chalcopyrite.

The specimen from the Rendaiji mine is found in "chalcocite"quartz ore in the form of minute lamellar aggregates with digenite.

* Eugene H. Roseboom, Jr. (Am. Mineral., in press) independently has found the same mineral from a number of localities. He and the writer have agreed to use the name djurleitc. 
Table 1. X-ray powder data for synthetic $\mathrm{Cu}_{1.96} \mathrm{~S}$, djurleite and chalcocite.

\begin{tabular}{|c|c|c|c|c|c|c|c|c|c|}
\hline \multicolumn{2}{|c|}{1} & \multicolumn{2}{|c|}{2} & \multicolumn{2}{|c|}{3} & \multicolumn{2}{|c|}{4} & \multicolumn{2}{|c|}{5} \\
\hline$d(\AA)$ & $I$ & $d(\AA)$ & $I$ & $d(\AA \AA)$ & $I$ & $d(\AA)$ & $I$ & $d(\hat{\mathrm{A}})$ & $I$ \\
\hline 4. 29 & $w$ & 4. 30 & 10 & $\begin{array}{l}\text { 4. } 31 \\
\text { 4. } 10\end{array}$ & $\begin{array}{l}6 \\
6\end{array}$ & 4.29 & 6 & & \\
\hline 3. 89 & $w$ & 3.89 & 16 & & & & & & \\
\hline 3. 75 & $\mathrm{~m}$ & 3. 75 & 13 & 3.77 & 10 & 3. 76 & 6 & $\begin{array}{l}3.73 \\
3.66\end{array}$ & $\begin{array}{l}32 \\
17\end{array}$ \\
\hline 3. 58 & $w$ & 3. 60 & 10 & & & & & 3.60 & 20 \\
\hline 3. 38 & $\mathrm{~m}$ & 3. 38 & 33 & 3. 39 & 31 & 3. 38 & 25 & $\begin{array}{l}\text { 3. } 37 \\
\text { 3. } 31\end{array}$ & $\begin{array}{l}17 \\
50\end{array}$ \\
\hline 3. 28 & $w$ & 3. 27 & 7 & 3. 29 & 13 & 3. 29 & 6 & 3.28 & 38 \\
\hline 3. 19 & $w$ & 3. 19 & 16 & 3.20 & 20 & 3. 20 & 10 & 3. 18 & 55 \\
\hline 3.10 & w & 3. 09 & 10 & 3.10 & 10 & & & & \\
\hline 3. 04 & $w$ & 3. 03 & 18 & 3.04 & 20 & 3. 03 & 13 & 3. 05 & 30 \\
\hline 3. 01 & $\mathbf{w}$ & 3. 01 & 20 & & & & & & \\
\hline $\begin{array}{l}2.96 \\
2.94\end{array}$ & $\begin{array}{l}\mathrm{w} \\
\mathrm{w}\end{array}$ & & & 2.97 & 6 & 2.97 & 13 & 295 & 46 \\
\hline $\begin{array}{l}\text { 2. } 94 \\
2.89\end{array}$ & w & 2.89 & 7 & 2. 89 & 22 & 2. 89 & 13 & & 40 \\
\hline 2.88 & $\mathrm{w}$ & 2.88 & 7 & & & & & & \\
\hline 2.86 & $w$ & 2.87 & 10 & & & & & 2. 86 & 17 \\
\hline 2. 83 & $w$ & 2. 82 & 15 & 2.83 & 12 & 2. 83 & 10 & & \\
\hline 2. 81 & $w$ & 2.81 & 13 & & & & & 2.81 & 13 \\
\hline 2.78 & $w$ & 2. 78 & 7 & 2. 79 & 10 & 2. 79 & 13 & & \\
\hline & & 2.74 & 9 & 2.73 & 15 & & & $\begin{array}{l}2.76 \\
2.72\end{array}$ & $\begin{array}{l}17 \\
65\end{array}$ \\
\hline 2. 69 & $\mathrm{w}$ & & & & & & & & \\
\hline 2.65 & w & 2.66 & 5 & 2.67 & 12 & 2.66 & 10 & 2.66 & 30 \\
\hline 2.60 & $\mathrm{w}$ & 2. 59 & 13 & & & & & & \\
\hline $\begin{array}{l}2.56 \\
2.5 ?\end{array}$ & $\mathrm{~W}$ & $\begin{array}{l}2.56 \\
2.51\end{array}$ & 13 & 2. 56 & 10 & 2. 56 & 13 & & \\
\hline 2.48 & $\begin{array}{l}w \\
w\end{array}$ & $\begin{array}{l}\text { 2. } \\
\text { 2. } 47\end{array}$ & $\begin{array}{l}9 \\
7\end{array}$ & 2. 52 & 10 & 2.52 & 15 & $\begin{array}{l}\text { 2. } 53 \\
2.47\end{array}$ & $\begin{array}{l}33 \\
48\end{array}$ \\
\hline 241 & $w$ & & & & & & & 2.43 & 13 \\
\hline $\begin{array}{l}.41 \\
2.39\end{array}$ & st & $\begin{array}{l}2.41 \\
2.39\end{array}$ & $\begin{array}{r}5 \\
82\end{array}$ & 239 & 85 & 230 & $0 ?$ & 240 & \\
\hline & & 2. 36 & 9 & & & 2.39 & 83 & 2.40 & 18 \\
\hline 2. 32 & w & 2. 32 & 10 & & & & & 2. 33 & 33 \\
\hline 2.29 & W & 2. 27 & 9 & & & & & 2.24 & 25 \\
\hline & & 2. 20 & 10 & & & & & 2. 21 & 25 \\
\hline 2. 14 & $\mathrm{w}$ & $\begin{array}{l}2.18 \\
2.14\end{array}$ & $\begin{array}{l}9 \\
5\end{array}$ & & & & & & \\
\hline 211 & $\mathrm{~W}$ & 211 & & & & & & 2. 12 & 13 \\
\hline 2.07 & $\mathrm{w}$ & 2. 07 & 7 & & & 2.07 & 10 & & \\
\hline 2.05 & $w$ & 2.05 & 9 & & & & & 2.02 & 13 \\
\hline 1. 963 & $\mathrm{~m}$ & 1. 96 & 100 & 1.96 & 100 & 1. 96 & 100 & 1. 97 & 100 \\
\hline & $1 \mathrm{M}$ & 1. 94 & 18 & 1. 94 & 15 & 1. 93 & 28 & 1.95 & 17 \\
\hline 1.87 & st & $\begin{array}{l}1.92 \\
1.87\end{array}$ & 96 & 1.87 & 91 & 1. 87 & 97 & 1. 88 & 96 \\
\hline
\end{tabular}




\section{$X$-ray studies}

The X-ray powder patterns of minerals from the localities mentioned above, were obtained by means of the Norelco diffractometer. They agree completely with the data of the synthetic $\mathrm{Cu}_{1.96} \mathrm{~S}$ given by Djurle. In Table 1, the powder data of some of the materials are given together with those of the synthetic $\mathrm{Cu}_{1.96} \mathrm{~S}$ by Djurle. For comparison, the data of chalcocite from the St. Ires Consols mine, Redruth, Cornwall, England (U.S. National Museum No. R-7909), are also given in the same table.

No appreciable displacements of corresponding peak positions are observed in the powder patterns of all djurleite specimens examined. This suggests a narrow, if any, solid solution range.

The principal points of distinction between chalcocite and djurleite in powder patterns are that strong reflections with $d$-values of $3.31 \AA$. and $2.72 \AA$. for chalcocite are either very weak or not observed for djurleite and that the three strongest reflections with $d$-values of $1.96 \AA$., $1.87 \AA$. and $2.39 \AA$. for djurleite are displaced to smaller $\theta$ values for chalcocite. If the amount of djurleite, however, is very small in chalcocite, idenfication of djurleite, only by the $\mathrm{X}$-ray powder method, is difficult.

One of the precession photographs of the specimen from the Ani mine is compared in Fig. 1 with that of the material synthesized by Kullerud. They show almost the same patterns, except small intensity differences between the corresponding reflections. Although

Table 1 (cont.)

1. Synthetic $\mathrm{Cu}_{1.96} \mathrm{~S}$ (Djurle, 1958)2). The $d$-values are calculated from $\sin ^{2} \theta$ 's given by Djurle.

2. Djurleite, the Osarizawa mine, Akita, Japan ( $\mathrm{Cu} / \mathrm{Ni}$ radiation).

3. Djurleite, the Leonard mine, Butte, Montana, U.S. A. (Cu/Ni radiation).

4. Djurleite, the Rendaiji mine, Shizuoka, Japan ( $\mathrm{Cu} / \mathrm{Ni}$ radiation).

5. Chalcocite, the St. Ires Consols mine, Redruth, Cornwall, England ( $\mathrm{Cu} / \mathrm{Ni}$ radiation). 
the patterns show the same fundamental reflections as those of digenite and bornite (Morimoto and Kullerud, 1959) ${ }^{5}$, the distribution of subsidiary reflections is quite different. These subsidiary reflections, suggesting the existence of some kind of long range ordering, make it difficult to determine the accurate cell dimensions and the space group. The symmetry obtained is orthorhombic.

\section{Chemical composition}

The chemical composition of the material from the Osarizawa mine was given as shown in Table 2 .

Table 2. Chemical composition of djurleite.

\begin{tabular}{l|ccc}
\hline & 1 & 2 & 3 \\
\hline $\mathrm{Cu}$ & $79.86 \%$ & $79.52 \%$ & $77.57 \%$ \\
$\mathrm{Fe}$ & - & - & 0.51 \\
$\mathrm{~S}$ & 20.14 & 20.48 & 20.66 \\
Rem. & & & 0.37 \\
\hline Total & $100.00 \%$ & $100.00 \%$ & $99.11 \%$ \\
\hline
\end{tabular}

1. Theoretical $\mathrm{Cu}_{2} \mathrm{~S}$.

2. Theoretical $\mathrm{Cu}_{1,96} \mathrm{~S}$.

3. Djurleite from the Osarizawa mine (analyst $\mathrm{S}$. Shimizu, 1906) ${ }^{4)}$ 9).
The chemical formula calculated from the result obtained by Shimizu is $\mathrm{Cu}_{1.91} \mathrm{Fe}_{0.01} \mathrm{~S}$. According to the microscope observations, which will be discussed below, djurleite is so closely interlaminated with digenite in most cases that com ${ }^{2}$ plete separation is not possible. The result of the chemical analysis given above, therefore, only represents the composition of a djurleite-digenite mixture.

\section{Microscope observations}

All the polished sections were mounted in cold setting plastic. Under the microscope, djurleite was observed to occur as:

(a) Minute intermixed lamellae of mostly djurleite and digenite. The lamellae appear to have formed along octahedral planes as a result of unmixing (Ani and Rendaiji mines). This texture may be identical with the "lamellaren Kupferglanz" described by Ramdohr".

(b) Aggregates of djurleite forming relatively large grains with very fine grains of digenite (Leonard mine). 
Mineralogical Journal, Vol. 3.

N. Morimoto, Plate I
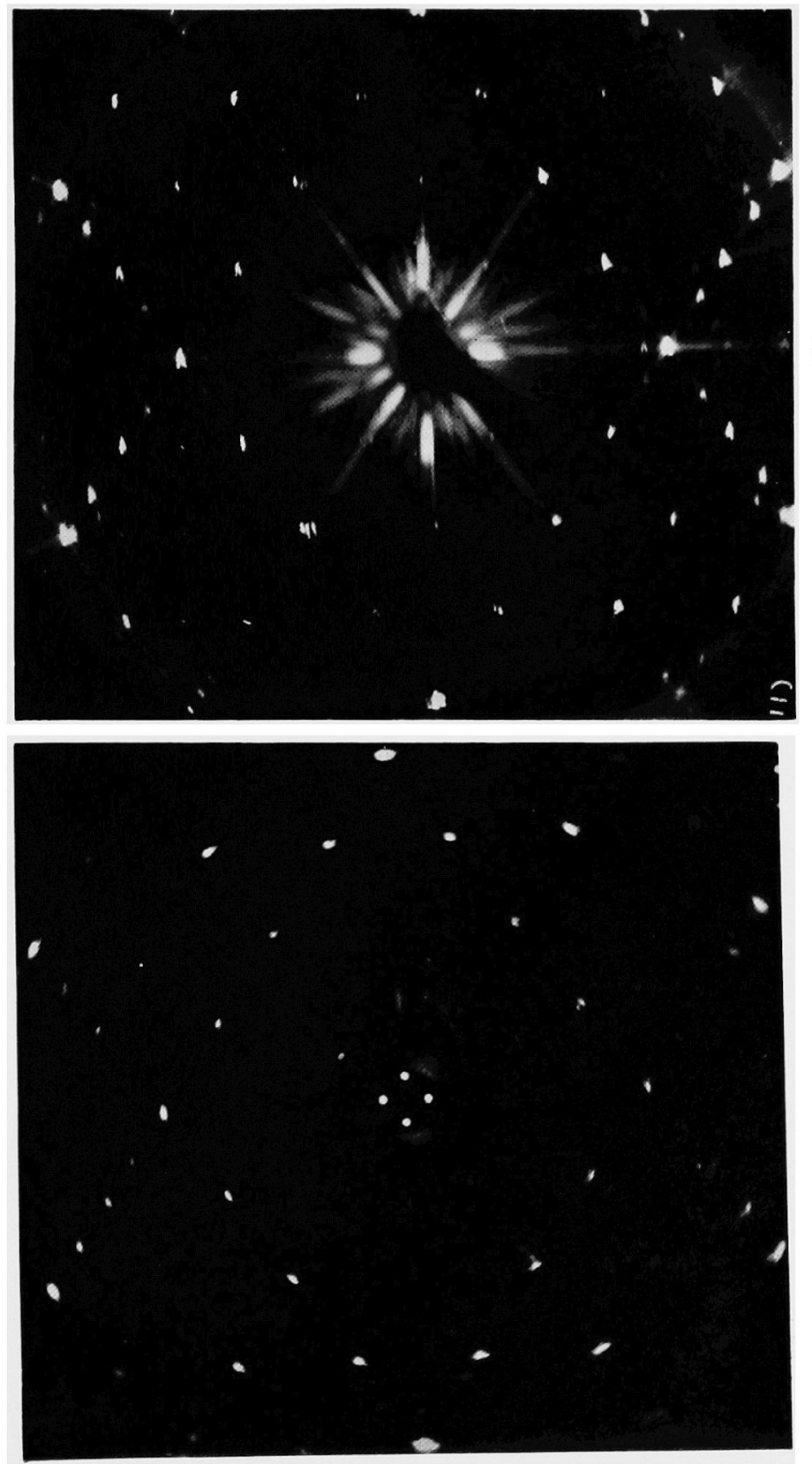

$\stackrel{2}{2}$

हี

ล

e

돈

을

สิ

$\stackrel{\Xi}{\Xi}$

E

$\stackrel{5}{\square}$

్ㅜㄹ

$\stackrel{1}{*}$

䍡

ส

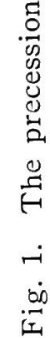


(c) Extremely fine intermixed grains of both djurleite and digenite (Osarizawa mine).

Bornite, chalcopyrite and pyrite are observed in association with djurleite in some specimens. Chalcocite associated with djurleite, however, has not been observed so far.

In reflected light, djurleite is less bluish than digenite and its reflectivity is higher than both that of digenite and that of bornite in air as well as in oil. Using polarized light, djurleite is moderately anisotropic and changes from bluish to yellowish tint. The polishing-, and scratching-hardnesses of djurleite are almost identical with those of digenite.

\section{Stability}

According to Djurle, this $\mathrm{Cu}_{1.96} \mathrm{~S}$ phase is present in synthetic samples of compositions between $\mathrm{Cu}_{1.82} \mathrm{~S}$ to $\mathrm{Cu}_{1.99} \mathrm{~S}$ quenched from $400^{\circ} \mathrm{C}$. and between $\mathrm{Cu}_{1.84} \mathrm{~S}$ to $\mathrm{Cu}_{1.99} \mathrm{~S}$ quenched from $75^{\circ} \mathrm{C}$. Its lowtemperature form with low symmetry transforms to a high-temperature form with cubic symmetry at about $100^{\circ} \mathrm{C}$. Roseboom ${ }^{8)}$ has, however, reported that the high-temperature form is tetragonal and breaks down, on heating, into digenite plus chalcocite, the reaction being reversible and occurring between $100^{\circ}$ and $150^{\circ} \mathrm{C}$. These results suggest that chalcocite and digenite may contain small amounts of djurleite in nature, although chalcocite coexisting with djurleite has not been found.

All the specimens of djurleite so far identified were previously believed to be chalcocite. This suggests that many specimens labelled chalcocite, especially co-existing with digenite, may really be djurleite.

\section{Acknowledgements}

The morphological and X-ray single crystal studies and the chemical analyses on djurleite from various localities were undertaken in the Mineralogical Department, University of Tokyo.

The writer expresses his thanks to Professor R. Sadanaga, T. 
Watanabe and A. Miyashiro for their interests in this work and for reviewing the manuscript. The writer is indebted to Dr. K. Sakurai and $\mathrm{Mr}$. T. Aoki for supplying him with material from the Ani mine, and to Dr. G. Switzer for the material from the Leonard mine. The writer is also indebted to Dr. G. Kullerud for his synthesis of single crystals of djurleite and for critically reading the manuscript, to Dr. J.W.Greig for his suggestion and microscope observation on the material from the Ani mine, and to Dr. A. Kato for his preparing polished sections and his help in microscope observations. Drs. T. Kato, F. Marumo and Mr. M. Ohmasa kindly helped the writer in this study.

\section{REFERENCES}

1) Dana, E. S.: System of Mineralogy, 6th Ed., 56 (1900).

2). Djurle, S.: Acta Chem. Scand., 12, 1415 (1958).

3) Jimbo, K.: Jour. Geol. Soc. Tokyo, 11, 387 (1904) (in Japanese).

4) Harada, Z.: Jour. Fac. Sci. Hokkaido Imp. Univ., Ser. IV, 3, 221 (1936).

5) Morimoto, N. and G. Kullerud: Carnegie Inst. of Washington, Year Book, 1959-1960, 116 (1959).

6) Morimoto, N. and G. Kullerud: Amer. Miner., 46, 1270 (1961).

7) Ramdohr, P.: Erzmineralien und ihre Verwachsungen, 410: AkademieVerlag, Berlin (1960).

8) Roseboom, E.H.: Abst, in Program 1960 Annual Meetings of Geol. Soc. Amer., etc. 191 (1960).

9) Wada, T.: Beitr. z. Mineral. v. Japan, Nr. 2, 55 (1906).

Manuscript received Jan. 7, 1962. 